\title{
Thermodynamic properties for different equilibrium moisture content in sunn hemp seeds ${ }^{1}$
}

\author{
Suian José Granella ${ }^{2 *}$, Divair Christ ${ }^{2}$, Taise Raquel Bechlin², Ivan Werncke ${ }^{2}$, \\ Silvia Renata Machado Coelho ${ }^{2}$
}

\begin{abstract}
Losses of agroindustry are generally wet products that must be dried to posterior use and storage. In order to optimize drying processes, the study of isotherms and thermodynamic properties become essential to understand the water sorption mechanisms of agricultural products. Thus, the objective in this study was to determine and evaluate the thermodynamic properties for different equilibrium moisture contents in sunn hemp (Crotalaria spectabilis Roth) seeds, using the direct static method to obtain the experimental data. The Chung-Pfost model was used to determine the thermodynamic properties of sunn hemp seeds. In according to results, thermodynamic properties were influenced by moisture content. The water vaporization latent heat increased with the decrease in equilibrium moisture content. The sunn hemp desorption process was controlled by entropy. Gibbs free energy is negative indicating that the desorption process of sunn hemp seeds was spontaneous.
\end{abstract}

Index terms: desorption of water, latent heat, enthalpy, entropy, Gibbs free energy.

\section{Propriedades termodinâmicas de sementes de crotalária}

\begin{abstract}
RESUMO - As perdas da agroindústria são geralmente de produtos úmidos que devem ser secos para posterior uso e armazenamento. Para otimizar os processos de secagem, o estudo das isotermas e propriedades termodinâmicas torna-se essencial para entender os mecanismos de sorção de água dos produtos agrícolas. Assim, o objetivo neste estudo foi determinar e avaliar as propriedades termodinâmicas para diferentes teores de água de equilíbrio em sementes de crotalária (Crotalaria spectabilis Roth), usando o método estático direto para obter os dados experimentais. O modelo de Chung-Pfost foi usado para determinar as propriedades termodinâmicas de sementes de crotalária. De acordo com os resultados, as propriedades termodinâmicas são influenciadas pelo teor de água. O calor latente da vaporização de água aumentou com a diminuição do teor de umidade de equilíbrio. O processo de dessorção das sementes de crotalária foi controlado pela entropia. A energia livre de Gibbs foi negativa, indicando que o processo de dessorção de sementes de crotalária foi espontâneo.
\end{abstract}

Termos para indexação: dessorção de água, calor latente, entalpia, entropia, energia livre de Gibbs.

\section{Introduction}

Sunn hemp is an important legume used to protect soils against erosion. It also reduces soil compaction, promotes significant nutrient recycling, suppresses pathogens, weeds and nematodes and supplies high quality fiber for manufacturing specialized paper products (Silva et al., 2012). Species as Crotalaria spectabilis, also mentioned of push- pull plants, bring beneficial consequences to control pests (Hassanali et al., 2008; Pickett et al., 2014).

However, the post-harvest processes to maintain grains and seeds quality after the harvest must be known. The drying process stands out among the processes most widely used to maintain the quality of agricultural products after harvesting (Silva et al., 2016).

The study of drying provides information on the heat and mass transfer that occur between the biological material and the

\footnotetext{
${ }^{1}$ Submitted on 11/29/2017. Accepted for publication on $05 / 30 / 2018$.

${ }^{2}$ Programa de Pós-graduação em Engenharia Agrícola, PGEAGRI/Unioeste, 85819-110 - Cascavel, PR, Brasil.

*Corresponding author <suiangranella@hotmail.com>
} 
drying element. This fact justifies the study of thermodynamic involved in the drying of agricultural products, allowing engineers to design better drying equipment, to calculate energy requirements necessary for the process, to study the properties of adsorbed water, to evaluate the microstructure of food and to study the physical phenomena that occur at the material surface (Corrêa et al., 2010).

The study of the thermodynamic properties is important also to predict the end at which the fruit should be dried in order to obtain a product that can be stored for long periods, consuming a minimum amount of energy to reduce the moisture content to safe storage levels (Resende et al., 2017).

Thus, this work aims to determine the thermodynamic properties of sunn hemp seeds as a function of equilibrium moisture content.

\section{Material and Methods}

\section{Sampling}

Samples of sunn hemp seeds (Crotalaria spectabilis Roth) were obtained from commercial production Western ParanáBrazil. The initial moisture content of sunn hemp seeds was about 24,8 (\%, dried base) and was determined using the gravimetric method, which consists of placing a small number of seeds in a forced air oven at $105^{\circ} \mathrm{C}$ for $24 \mathrm{~h}$ (Brasil, 2009).

\section{Moisture Content Equilibrium}

The static-gravimetric method was used to obtain the hygroscopic equilibrium moisture content and, for each replication approximately $5.0 \mathrm{~g}$ of seeds were placed in sealed containers containing saturated solutions of different salts (potassium acetate, magnesium chloride, potassium carbonate, sodium nitrate, potassium iodide, sodium chloride and potassium chloride) used for keeping constant the relative humidity inside of containers.

The Chung-Pfost model was used in order to determine the sunn hemp seeds thermodynamic properties, because it presented the best fit to the experimental data, with the coefficient of determination, estimated mean error (SE), and mean relative error $(\mathrm{P})$ of $86.07 \% ; 0.014$; and $6.10 \%$, respectively. The values of water activity were obtained according to the formula:

$$
\begin{aligned}
& \mathrm{X}_{\mathrm{e}}=30.6907^{* *}-4.3384^{* *} \cdot \ln \left[-\left(\mathrm{T}+53.3563^{* *}\right) \cdot \ln \left(\mathrm{A}_{\mathrm{w}}\right)\right. \\
& * * \text { significant at } 5 \% \text { by t-test, where: } \\
& \mathrm{X}_{\mathrm{e}}=\text { equilibrium moisture content }(\%, \mathrm{db}) ; \\
& \mathrm{A}_{\mathrm{w}}=\text { water activity }(\text { decimal }) ; \text { and } \\
& \mathrm{T}=\text { temperature }\left({ }^{\circ} \mathrm{C}\right) .
\end{aligned}
$$

\section{Thermodynamic Properties}

The following equation was used to quantifying partial vapor pressure contained in porous systems, reference to the Clausius-Clapeyron studies, according to Brooker et al. (1992):

$\operatorname{Ln}(\mathrm{Pv})=\left(\left(\frac{\mathrm{L}}{\mathrm{L}^{\prime}}\right) \cdot \operatorname{Ln}(\mathrm{Pvs})+\mathrm{C}\right.$, where:

Pvs $=$ free water saturation vapor pressure for a given temperature $(\mathrm{T})$ of equilibrium;

$\mathrm{Pv}=$ free water vapor pressure at a given temperature $\mathrm{T}$, of equilibrium;

$\mathrm{L}=$ latent heat of product water vaporization $\left(\mathrm{kJ}^{\mathrm{kg}} \mathrm{kg}^{-1}\right)$;

$\mathrm{L}^{\prime}=$ latent heat of free water vaporization, equilibrium temperature $\left(\mathrm{kJ}^{\mathrm{kg}} \mathrm{kg}^{-1}\right)$; and

$\mathrm{C}=$ integration constant.

Based on the sorption isotherms of sunn hemp seeds, the $\mathrm{L} / \mathrm{L}$ ' ratio was determined for different equilibrium moisture contents. The equation was adjusted for water vaporization enthalpy, presented by Rodrigues - Arias (Brooker et al., 1992), with the inclusion of one more parameter in the following equation to improve L/L' estimates, proposed by Corrêa et al. (1998):

$\frac{\mathrm{L}}{\mathrm{L}^{\prime}}-1=\mathrm{a} \cdot \operatorname{Exp}\left(-\mathrm{b} \cdot \mathrm{X}_{\mathrm{e}}^{\mathrm{m}}\right), \quad$ where:

$\mathrm{a}, \mathrm{b}, \mathrm{m}=$ parameters determined by regression.

The latent heat of free water vaporization $\left(\mathrm{kJ} \mathrm{kg}^{-1}\right)$ at equilibrium temperature $\left({ }^{\circ} \mathrm{C}\right)$ was calculated using the mean temperature $(\mathrm{T})$ within the study range, using the following equation:

\section{$\mathrm{L}^{\prime}=2502.2-2.39 \cdot \mathrm{T}$}

The free water saturation vapor pressure, Pvs, was calculated by the Thétens equation:

$$
\mathrm{Pvs}=0.61078 \cdot 10^{[(7.5 . \mathrm{T}) /(273.3+\mathrm{T})]}
$$

The vapor pressure value, $\mathrm{Pv}$, was determined according to the following equation:

$$
\mathrm{Pv}=\mathrm{A}_{\mathrm{w}} \cdot \mathrm{Pvs}
$$

The latent heat of the product vaporization water was determined according to following formula proposed by Corrêa et al. (1998):

$$
\mathrm{L}=(2502.2-2.39 \cdot \mathrm{T}) \cdot\left[1+\mathrm{a} \cdot \operatorname{Exp}\left(-\mathrm{b} \cdot \mathrm{X}_{\mathrm{e}}{ }^{\mathrm{m})}\right]\right.
$$

The differential entropy of sorption was calculated according to the equation:

$$
\begin{aligned}
& S=\frac{h s t-G}{T_{a b s}} \text {, where: } \\
& \mathrm{S}=\text { differential entropy of sorption }\left(\mathrm{kJ} \mathrm{kg}^{-1} \mathrm{~K}^{-1}\right) \text {; } \\
& \mathrm{G}=\text { Gibbs free energy }\left(\mathrm{kJ}^{\mathrm{kg}} \mathrm{kg}^{-1}\right) \text {; }
\end{aligned}
$$


$\mathrm{T}_{\mathrm{abs}}=$ absolute temperature (K);

$\mathrm{hst}=$ differential enthalpy, $\mathrm{kJ} \mathrm{kg}^{-1}$.

Gibbs free energy can be calculated by the following equation:

$\mathrm{G}=\mathrm{R} \cdot \mathrm{T}_{\mathrm{abs}} \cdot \ln \left(\mathrm{A}_{\mathrm{w}}\right)$

Changes in water sorption over free energy usually cause changes in enthalpy and entropy values. Thus, the following equation was rearranged according to the last two equations described:

The values of differential enthalpy of sorption (hst) and entropy (S) calculated were correlated by the following equation (Beristain et al., 1996):

hst $=\mathrm{T}_{\mathrm{B}} \cdot \mathrm{S}+\mathrm{G}_{\mathrm{B}}$, where:

$\mathrm{T}_{\mathrm{B}}=$ isokinetic temperature $(\mathrm{K})$; and

$\mathrm{G}_{\mathrm{B}}=$ Gibbs free energy at an isokinetic temperature $\left(\mathrm{kJ} . \mathrm{kg}^{-1}\right)$.

The isokinetic temperature represents the temperature at which all series reactions occur at the same rate. Since enthalpy and entropy are highly correlated, compensation theory is assumed for sorption (Beristain et al., 1996). In order to confirm the existence of compensation, the isokinetic temperature was compared to the harmonic mean of the temperatures used to determine the sorption isotherms, according to following equation (Krug et al., 1976):

$\mathrm{T}_{\mathrm{hm}}=\mathrm{n} / \sum(1 / \mathrm{T})$, where:

$\mathrm{T}_{\mathrm{hm}}=$ mean harmonic temperature $(\mathrm{K})$; and

$\mathrm{n}=$ number of temperatures used.

According to Krug et al. (1976), linear chemical compensation or compensation theory only exists if the isokinetic temperature $\left(T_{B}\right)$ is different from the mean harmonic temperature $\left(\mathrm{T}_{\mathrm{hm}}\right)$. An approximate confidence interval, (1- $\alpha) 100 \%$, for the isokinetic temperature was obtained by the following equation:

$\mathrm{T}_{\mathrm{B}}=\widehat{\mathrm{T}}_{\mathrm{B}} \pm \mathrm{t}_{\mathrm{m}-2, \alpha / 2 \sqrt{\operatorname{Var}\left(\mathrm{T}_{\mathrm{B}}\right)}}$

In which,

$\widehat{\mathrm{T}}_{\mathrm{B}}=\frac{\sum(\mathrm{hst}-\overline{\mathrm{hst}})(\mathrm{S}-\overline{\mathrm{S}})}{\sum(\mathrm{S}-\overline{\mathrm{S}})^{2}}$

and,

$\operatorname{Var}\left(\mathrm{T}_{\mathrm{B}}\right)=\frac{\sum\left(\mathrm{hst}-\overline{\mathrm{G}_{\mathrm{B}}}-\widehat{\mathrm{T}}_{\mathrm{B}} \mathrm{S}\right)^{2}}{(\mathrm{~m}-2) \sum(\mathrm{S}-\overline{\mathrm{S}})^{2}}$

where:

$\mathrm{m}=$ number of enthalpy and entropy data pairs;

$\overline{\mathrm{hst}}=$ mean enthalpy, $\mathrm{kJ}^{\mathrm{kg}}{ }^{-1}$; and
$\overline{\mathrm{S}}=$ mean entropy $\mathrm{kJ} . \mathrm{kg}^{-1}$.

If the harmonic mean temperature $\mathrm{T}_{\mathrm{hm}}$ is within the isokinetic temperature $T_{B}$ range calculated, the ratio between enthalpy values and the differential entropy of sorption reflects only experimental errors, not the existence of chemical and physical factors that govern the theory of compensation (Beristain et al., 1996). A 99\% confidence interval was adopted for $T_{B}$ throughout the data range observed.

The relative mean error $(\mathrm{P})$ was calculated according to the following expression:

$\mathrm{P}=(100 / \mathrm{n}) \sum(|\mathrm{Y}-\hat{\mathrm{Y}}|) / \mathrm{Y}$, where:

$\mathrm{Y}=$ experimental value;

$\hat{\mathrm{Y}}=$ value estimated by the model; and

$\mathrm{n}=$ number of experimental observations.

\section{Results and Discussion}

\section{Latent Heat and Water Activity}

Table 1 shows the water activity values estimated by the Chung-Pfost model, Equation (1), for the temperatures of 5, $10,15,25$, and $40^{\circ} \mathrm{C}$, and for equilibrium moisture contents of 8,3 to $24,8(\mathrm{db})$. There is an increase in water activity with the increase in moisture content, and the same effect is observed with increase in temperature. This behavior was reported by other authors when studying the thermodynamic properties of several agricultural products, such as quinoa (Tang et al., 2015) and peanut (Goneli et al., 2017).

Water activity values, Table 1 , were used to determine the differential enthalpy of desorption. Table 2 shows the values of the $\mathrm{L} / \mathrm{L}$ ' ratio for the different moisture contents. The $\mathrm{L} / \mathrm{L}$ ' ratio is increased by decreasing moisture contents.

The L/L' ratio values increase with moisture content reduction, and magnitudes were close to 1.0 for high moisture contents.

Table 3 shows the parameters "a", "b" and " $m$ " used to calculate the ratio between the latent heat of water vaporization in agricultural products (L), and the free water latent heat (L') obtained by means of non-linear regression. The regression equation can be used to estimate the latent vaporization heat of sunn hemp seeds, since it has a high coefficient of determination $\left(\mathrm{R}^{2}\right)$, and a low mean relative error $(\mathrm{P})$.

By changing the values of "a", " $b$ " and " $m$ " in the equation proposed by Corrêa et al. (1998), the following equation is obtained for the calculation of the latent heat of water vaporization in sunn hemp.

$\mathrm{L}=(2502.2-2.239 \cdot \mathrm{T}) \cdot[1+3.0343 \cdot \operatorname{Exp}(-0.2298 \cdot X \mathrm{Xe} 1.0006)$

Figure 1 shows the latent heat curves of water vaporization in sunn hemp seeds at temperatures of $5,10,15,25$ and $40^{\circ} \mathrm{C}$. 
Table 1. Water activity values (decimal) estimated by the Chung-Pfost model as a function of temperature and equilibrium moisture content.

\begin{tabular}{cccccc}
\hline \multirow{2}{*}{$\mathrm{Xe}(\% \mathrm{db})$} & \multicolumn{5}{c}{ Temperature $\left({ }^{\circ} \mathrm{C}\right)$} \\
\cline { 2 - 5 } & 5 & 10 & 15 & 25 & 40 \\
\hline 8.3 & 0.051 & 0.065 & 0.079 & 0.109 & 0.156 \\
10.4 & 0.157 & 0.182 & 0.206 & 0.252 & 0.314 \\
11.5 & 0.238 & 0.267 & 0.294 & 0.343 & 0.408 \\
12.7 & 0.340 & 0.370 & 0.398 & 0.448 & 0.510 \\
13.3 & 0.388 & 0.418 & 0.445 & 0.494 & 0.553 \\
13.7 & 0.427 & 0.457 & 0.484 & 0.531 & 0.587 \\
14.0 & 0.446 & 0.476 & 0.502 & 0.548 & 0.604 \\
14.4 & 0.481 & 0.510 & 0.535 & 0.580 & 0.633 \\
15.8 & 0.587 & 0.612 & 0.635 & 0.673 & 0.717 \\
16.9 & 0.660 & 0.682 & 0.701 & 0.734 & 0.772 \\
18.7 & 0.761 & 0.778 & 0.792 & 0.816 & 0.843 \\
20.0 & 0.816 & 0.829 & 0.841 & 0.860 & 0.881 \\
22.4 & 0.890 & 0.898 & 0.905 & 0.917 & 0.930 \\
24.8 & 0.935 & 0.940 & 0.945 & 0.952 & 0.959 \\
\hline
\end{tabular}

Table 2. Ratio between the latent heat of water vaporization in agricultural products (L) and the free water latent heat (L') for the different moisture contents in sunn hemp.

\begin{tabular}{cccc}
\hline $\begin{array}{c}\text { Moisture contente } \\
(\mathrm{db})\end{array}$ & $\begin{array}{c}\text { Ratio } \\
\text { L/L }\end{array}$ & $\begin{array}{c}\text { Moisture contente } \\
(\mathrm{db})\end{array}$ & $\begin{array}{c}\text { Ratio } \\
\mathrm{L} / \mathrm{L}\end{array}$ \\
\hline 8.3 & 1.4472 & 14.4 & 1.1101 \\
10.4 & 1.2788 & 15.8 & 1.0801 \\
11.5 & 1.2158 & 16.9 & 1.0625 \\
12.7 & 1.1622 & 18.7 & 1.0411 \\
13.3 & 1.1424 & 20.0 & 1.0306 \\
13.7 & 1.1279 & 22.4 & 1.0175 \\
14.0 & 1.1214 & 24.8 & 1.0101 \\
\hline
\end{tabular}

Table 3. Parameters "a", "b" and "m" used to calculate the ratio between the latent heat of water vaporization in agricultural products $(\mathrm{L})$ and the free water latent heat (L').

\begin{tabular}{ccccc}
\hline $\mathrm{a}$ & $\mathrm{b}$ & $\mathrm{m}$ & $\mathrm{R}^{2}(\%)$ & $\mathrm{P}(\%)$ \\
\hline $3.0343^{*}$ & $0.2298^{*}$ & $1.0006^{*}$ & 99.99 & 0.02 \\
\hline
\end{tabular}

*Significant at $5 \%$ by t-test.

The latent heat of vaporization is inversely proportional to sunn hemp seeds' moisture content and temperature, and the increase in temperature promoted reduction of the latent vaporization heat for the same moisture content (Figure 1). Similar observations have been reported for drying of alfalfa (Siles et al., 2015), pepper seeds (Silva et al., 2016) and grape

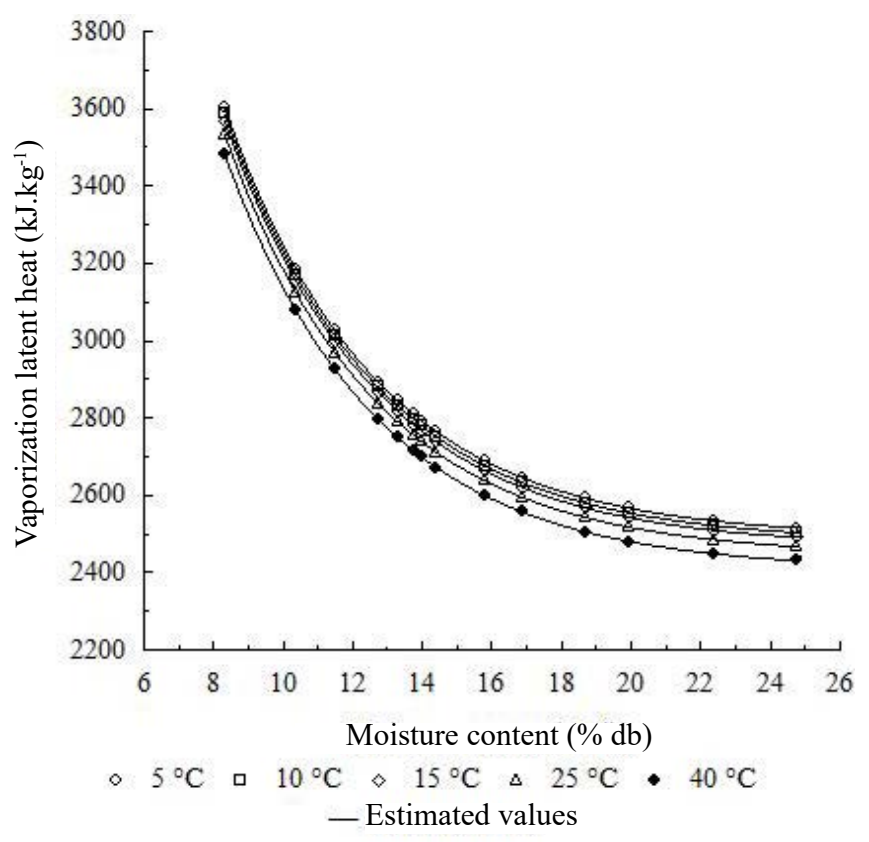

Figure 1. Experimental and estimated values of the latent heat of water vaporization as a function of equilibrium moisture content for sunn hemp seeds.

seeds (Maleki Majd et al., 2013).

The latent heat of sunn hemp seeds vaporization ranged from $3604.99-2430.85 \mathrm{~kJ} \mathrm{~kg}^{-1}$ for moisture contents of 8.3 to $24.8 \%$ (db). Brooker et al. (1992) emphasize that the latent heat of vaporization in the product is influenced mainly by moisture content and temperature. 


\section{Differential entropy and enthalpy}

The differential enthalpy and entropy of sunn hemp seeds were calculated from the isotherm obtained by the ChungPfost model. Figure 2 shows the values of differential enthalpy (hst) and differential entropy (S) of desorption, as a function of equilibrium moisture content $(\% \mathrm{db})$.

Differential enthalpy and entropy increase with moisture content reduction in sunn hemp seeds (Figure 2), similar effect was reported in previous studies also (Maleki Majd et al., 2013; Edrisi and Langrish, 2015; Resende et al., 2017).

Figure 2 shows that the differential enthalpy and entropy had a strong dependence on the moisture content, with higher values in lower equilibrium moisture. At moisture near the corresponding value of the monolayer, the differential enthalpy had higher values and to the extent that the values approach the multilayer water, the enthalpy decreased to values near $10 \mathrm{~kJ} . \mathrm{kg}^{-1}$. The maximum enthalpy value indicates the covering of the strongest binding sites and the greatest water-solid interaction and the covering of less favorable locations and the formation of multilayers then follows, as shown by the decrease in enthalpy with increasing moisture content (Liébanes et al., 2006; Maleki Majd et al., 2013). As the moisture content increases, the majority of sorption sites becomes occupied and sorption occurs in fewer available binding sites with lower energy, providing lower values of differential enthalpy (Xiao and Tong, 2013). On the other hand, since the entropy is an index of the irregularity in sorption, with increasing moisture content, irregularity of sorption will decrease.

The differential enthalpy and entropy values ranged

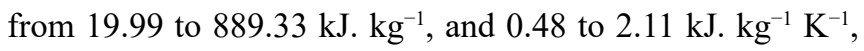
respectively, for the moisture content range from 8.3 to 24.8 $(\% \mathrm{db})$. This entropy behavior is related to water molecule mobility during the desorption process.

Table 4 presents the equations to determine differential enthalpy and entropy, as well as coefficients of determination for sunn hemp seeds. The equations presented high coefficients of determination and low relative mean error. In addition, all equation parameters were significant at $1 \%$ significance by the $\mathrm{t}$-test, evidencing the adequacy of the equations to the experimental data.

\section{Enthalpy-entropy compensation theory}

The compensatory theory proposes the existence of a linear relationship between the enthalpy and entropy of products subjected to water adsorption process. Beristain et al., (1996) demonstrated that the compensation allows understanding the mechanisms of controlling the water vapor adsorption in foods, and sugar rich foods exhibit only a straight compensation line and thus the adsorption process is controlled by enthalpy. Figure 3 shows the linear relationship between differential enthalpy and entropy of the sunn hemp seeds $\left(\mathrm{R}^{2}=99.99\right)$, indicating that the theory can be applied.

With the linearity between the differential enthalpy ratio and the differential entropy of sorption, the isokinetic theory, or enthalpy-entropy compensation theory for the water desorption phenomenon in sunn hemp seeds can be considered valid.

The isokinetic theory is evidenced by the fact that the harmonic mean temperature $\left(\mathrm{T}_{\mathrm{hm}}\right)$ calculated by the Krug test was $291.78 \mathrm{~K}$, whose value was significantly different from $T_{B}(120.27 \pm 6.12 \mathrm{~K})$ for the sunn hemp seeds. Thus, the adsorption process in this study is controlled by the entropy because of $T_{B}<T_{h m}$. However, when $T_{B}>T_{h m}$, the process is governed by enthalpy. These results are in agreement with the

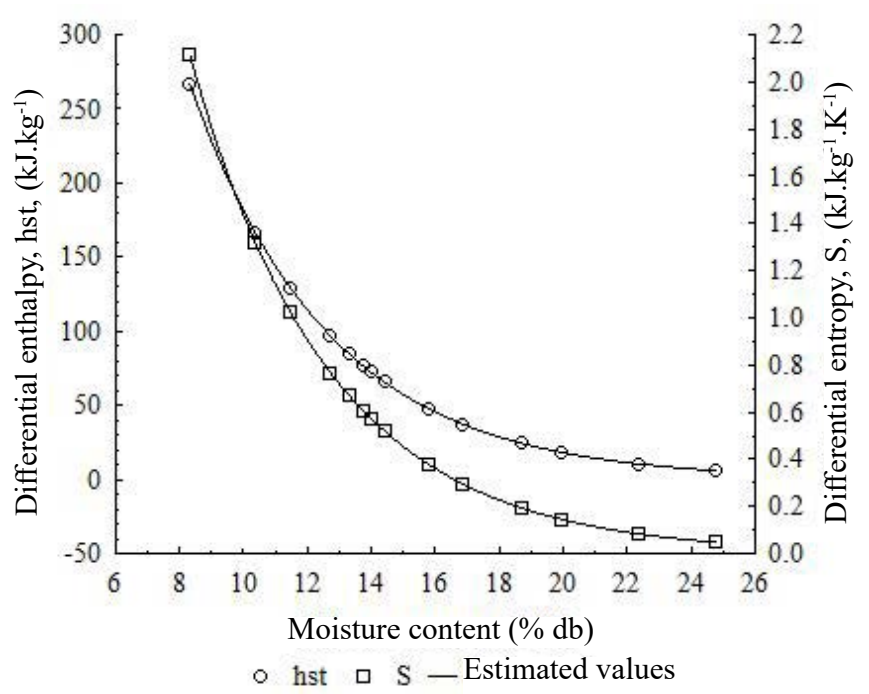

Figure 2. Values of differential enthalpy and entropy of desorption observed and estimated for sunn hemp seeds.

Table 4. Equations and coefficients of differential enthalpy (hst) and entropy (S) of desorption in sunn hemp.

\begin{tabular}{|c|c|c|c|}
\hline Thermodynamic properties & Equations & $\mathrm{R}^{2}(\%)$ & $\mathrm{P}(\%)$ \\
\hline Differential enthalpy & $\mathrm{hst}=1814.99 * * \cdot \operatorname{Exp}(-0.2304 * * \mathrm{Xe})$ & 99.99 & 0.0006 \\
\hline Differential entropy & $\mathrm{S}=14.37 * * \cdot \operatorname{Exp}(-0.2304 * * \mathrm{Xe})$ & 99.99 & 0.0005 \\
\hline
\end{tabular}

**Significant at $1 \%$ by t-test. 
previous investigations that the values of isokinetic theory lie with in the general range for biologics materials, and similar to jatropha grains (Santos and Martins, 2016) and castor beans (Goneli et al., 2016).

According to Spada et al. (2013), this theory allows us to check if there will be a greater molecular interaction due to the decrease in the number of links or molecules of the system, generating larger organization or order (related to the enthalpy) about the disorganization and, consequently, a greater freedom of molecules in the system (related to the entropy).

The Gibbs energy $(G)$ indicates the energy spontaneous interaction of the water-sorbent, providing a measure of the useful or available energy to the process. When $\mathrm{G}$ is negative, the process is said spontaneous, otherwise, the process is non-spontaneous (Apostolopoulos and Gilbert, 1990). The $\mathrm{G}$ obtained for the desorption process of sunn hemp seeds was $-91.82 \mathrm{~kJ}^{\mathrm{kg}} \mathrm{kg}^{-1}$, which indicates that the process occurs spontaneously.

Gibbs free energy values related to sunn hemp seeds in function of equilibrium moisture content $(\% \mathrm{db})$ are presented in Figure 4.

Table 5 presents mathematical models fitted and observed values of Gibbs free energy related in function of equilibrium moisture content. They can be used to predict Gibbs free energy values within the moisture content range between 8.3 and $24.8(\% \mathrm{db})$.

The equations presented high coefficients of determination and low relative mean error, and all the equation parameters were significant at $1 \%$ of significance by the t-test, so the Gibbs free energy can be determined for the temperatures studied. Note that the parameter $\alpha$ increased with increasing temperature and parameter $\beta$ was the same for all temperatures, as also was showed in Figure 4.

Thus, the values presented are expected (Figure 4), because at higher values of moisture content, there is the lower necessity of work to make the sites available to sorption, because they are already available. Negative values of this parameter are also expected, as it characterizes endothermic reaction, or else, reactions that require energy from the environment to occur.

Finally, moisture desorption isotherms and results obtained from thermodynamic properties can help to define suitable drying and storage conditions to improve the quality of sunn hemp seeds and enhance its value in the world trade.

\section{Conclusions}

Thermodynamic properties of sunn hemp seeds are influenced by moisture content, increasing the energy required

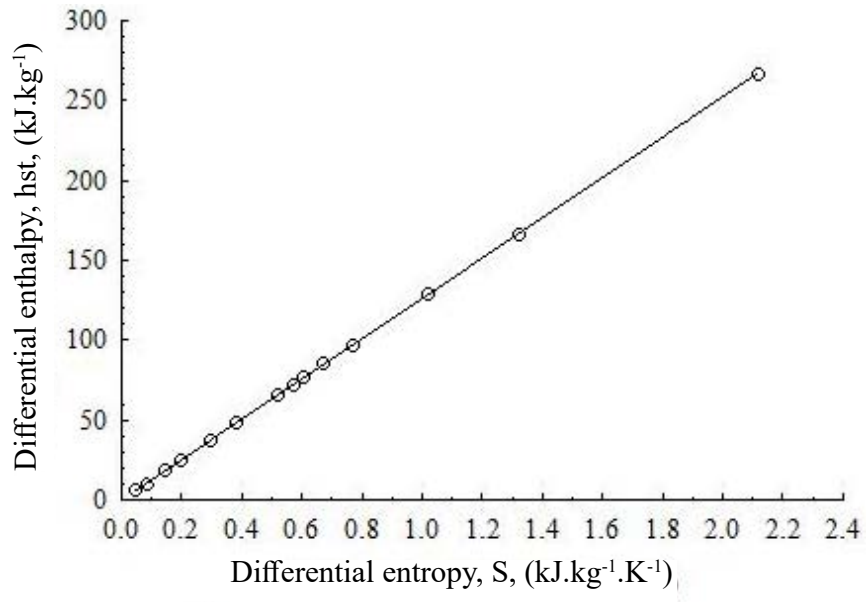

hst $=1.42 \mathrm{E}(-14)^{\mathrm{ns}}+126.27 * * \mathrm{~S}, \mathrm{R}^{2}=99.99 \%$

${ }^{\mathrm{ns}}$ non-significant, ${ }^{*}$ Significant at $1 \%$ by t-test

Figure 3. Enthalpy-entropy ratio for water desorption process in sunn hemp seeds.

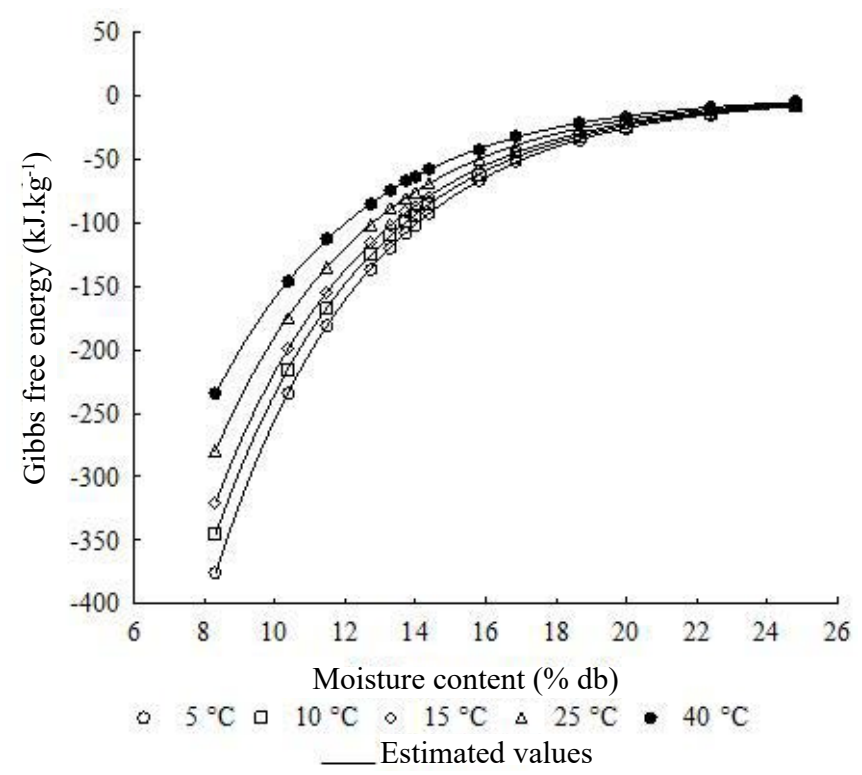

Figure 4. Observed and estimated values of Gibbs free energy for water desorption process in sunn hemp seeds.

Table 5. Mathematical models fitted to values of Gibbs free energy with equilibrium moisture content of sunn hemp seeds.

\begin{tabular}{cccr}
\hline Temperatura & Equations & $\mathrm{R}^{2}$ & $\mathrm{P}(\%)$ \\
\hline 5 & $\mathrm{G}=-2554.97^{* *} \operatorname{Exp}\left(-0.2305^{* *} \mathrm{Xe}\right)$ & 99.99 & 0.001 \\
10 & $\mathrm{G}=-2345.00^{* *} \operatorname{Exp}\left(-0.2302^{* * \mathrm{Xe})}\right.$ & 99.99 & 0.001 \\
15 & $\mathrm{G}=-2176.08^{* *} \operatorname{Exp}\left(-0.2303^{* * \mathrm{Xe})}\right.$ & 99.99 & 0.0007 \\
25 & $\mathrm{G}=-1900.28^{* *} \operatorname{Exp}\left(-0.2304^{* * \mathrm{Xe})}\right.$ & 99.99 & 0.0007 \\
40 & $\mathrm{G}=-1593.15^{* *} \operatorname{Exp}\left(-0.2303^{* * \mathrm{Xe})}\right.$ & 99.99 & 0.0007 \\
\hline
\end{tabular}

**Significant at $1 \%$ by t-test. 
for water removal from the product, with the reduction in moisture content. The differential enthalpy showed high values at low moisture contents, evidencing strong surface-water interaction in the samples. The differential entropy as well as the enthalpy exhibited a strong dependence on moisture, reaching minimum values at moisture contents above $20 \%$, which remained practically constant. Furthermore, the enthalpy-entropy compensation theory indicated that the sorption mechanism is controlled by entropy. In addition, Gibbs free energy showed negative values, indicating that the desorption process of sunn hemp seeds is endothermic and irreversible and occurs spontaneously.

\section{Acknowledgments}

The authors thank to CAPES-Coordenação de Aperfeiçoamento de Pessoal de Nível Superior (Coordination for the Improvement of Higher Education Personnel) for supporting part of this research.

\section{References}

APOSTOLOPOULOS, D.; GILBERT, S. G. Water sorption of coffee solubles by frontal inverse gas chromotography: thermodynamic considerations. Journal of Food Science, v.55, n.2, p.475-487, 1990. https://doi.org/10.1111/j.1365-2621.1990.tb06790.x

BERISTAIN, C.I.; GARCIA, H.S.; AZUARA, E. EnthalpyEntropy compensation in food vapor adsorption. Journal of Food Engineering, v.30, n.3-4, p.405-415, 1996. http://linkinghub. elsevier.com/retrieve/pii/S0260877496000118.

BRASIL. Ministério da Agricultura, Pecuária e Abastecimento. Regras para análise de sementes. Ministério da Agricultura, Pecuária e Abastecimento. Secretaria de Defesa Agropecuária. Brasília, DF: MAPA/ACS, 2009. 395p. http://www.agricultura.gov.br/arq_editor/ file/2946_regras_analise_sementes.pdf

BROOKER, D.B.; BAKKER-ARKEMA, F.W.; HALL, W. Drying and storage of grains and oilseeds. New York: Van Nostrand Reinhold, 1992. 495p. http://www.springer.com/la/book/9780442205157

CORRÊA, P.C.; CHRIST, D.; MARTINS, J.H.; MANTOVANI, B.H.M. Curvas de dessorção e calor latente de vaporização para as sementes de milho pipoca (Zea mays). Revista Brasileira de Engenharia Agrícola e Ambiental, v.2, n.1, p.75-79, 1998. http://www.scielo.br/scielo.php?script=sci_arttext\&pid=S141543661998000100075\&lng=pt\&tlng $=\mathrm{pt}$

CORRÊA, P.C.; OLIVEIRA, G.H.H.; BOTELHO, F.M.; GONELI, A.L.D.; CARVALHO, F.M. Modelagem matemática e determinação das propriedades termodinâmicas do café (Coffea arabica L.) durante o processo de secagem. Revista Ceres, v.57, n.5, p.595-601, 2010. http://www.scielo.br/scielo.php?script $=$ sci arttext\&pid=S0034737 X2010000500005\&lng=pt\&tlng=pt
EDRISI, S. M.; LANGRISH, T.A.G. Moisture sorption isotherms and net isosteric heat of sorption for spray-dried pure orange juice powder. LWT - Food Science and Technology, v.62, n.1, p. 875-882, 2015. https://doi.org/10.1016/j.lwt.2014.09.064

GONELI, A.L.D.; ARAUJO, W.D.; HARTMANN FILHO, C.P.; MARTINS, E.A.S.; OBA, G.C. Drying Kinetic peanut kernels drying in thin layer. Engenharia Agrícola, v.37, n.5, p.994-1003, 2017. http://www.scielo.br/scielo.php?script=sci_arttext\&pid=S010069162017000500994\&lng=en\&tlng=en.

GONELI, A.L.D.; CORRÊA, P.C.; OLIVEIRA, G.H.H.; RESENDE, O.; MAUAD, M. Moisture sorption isotherms of castor beans. Part 1: Mathematical modeling and hysteresis. Revista Brasileira de Engenharia Agrícola e Ambiental, v.20, n.8, p.751-756, 2016. http:// dx.doi.org/10.1590/1807-1929/agriambi.v20n8p751-756

HASSANALI, A.; HERREN, H.; KHAN, Z.R.; PICKETT, J.A.; WOODCOCK, C.M. Integrated pest management: the pushpull approach for controlling insect pests and weeds of cereals, and its potential for other agricultural systems including animal husbandry. Philosophical Transactions of the Royal Society B: Biological Sciences, v.363, n.1491, p.611-621, 2008. http://rstb. royalsocietypublishing.org/cgi/doi/10.1098/rstb.2007.2173

KRUG, R.R.; HUNTER, W.G.; GRIEGER, R.A. Enthalpy-entropy compensation. 1. Some fundamental statistical problems associated with the analysis of van't Hoff and Arrhenius data. The Journal of Physical Chemistry, v.80, n.21, p.2335-2341, 1976. http://dx.doi. org/ $10.1021 / \mathrm{j} 100562 \mathrm{a} 006$

LIÉBANES, M.D.; ARAGÓN, J.M.; PALANCAR, M.C.; ARÉVALO, G.; JIMÉNEZ, D. Equilibrium moisture isotherms of two-phase solid olive oil by-products: Adsorption process thermodynamics. Colloids and Surfaces A: Physicochemical and Engineering Aspects, v.282-283, p. 298-306, 2006. https://doi. org/10.1016/j.colsurfa.2006.03.025

MALEKI MAJD, K.; KARPARVARFARD, S.H.; FARAHNAKY, A.; JAFARPOUR, K. Thermodynamic of water sorption of grape seed: temperature effect of sorption isotherms and thermodynamic characteristics. Food Biophysics, v.8, n.1, p.1-11, 2013. https://doi. org/10.1007/s11483-012-9274-Z

PICKETT, J.A.; WOODCOCK, C.M.; MIDEGA, C.A.O.; KHAN, Z.R. Push-pull farming systems. Current Opinion in Biotechnology, v.26, p.125-132, 2014. https://doi.org/10.1016/j.copbio.2013.12.006

RESENDE, O.; OLIVEIRA, D.E.C.; COSTA, L.M.; JÚNIOR, W.N.F. Thermodynamic properties of baru fruits (Dipteryx alata Vogel ). Engenharia Agrícola, v.37, n.4, p.739-749, 2017. http:// dx.doi.org/10.1590/1809-4430-eng.agric.v37n4p739-749/2017

SANTOS, S.B.; MARTINS, M.A. Equilibrium moisture and thermodynamic properties on desorption process of Jatropha seeds. Journal of Chemical Engineering \& Process Technology, v.7, n.5, p.1-8, 2016. http://doi.org/10.4172/2157-7048.1000318

SILES, J.A.; GONZÁLEZ-TELLO, P.; MARTÍN, M.A.; MARTÍN, A. Kinetics of alfalfa drying: Simultaneous modelling of moisture content and temperature. Biosystems Engineering, v.129, p.185-196, 2015. https://doi.org/10.1016/j.biosystemseng.2014.10.007 
SILVA, C.B.; LOPES, M. M.; MARCOS-FILHO, J.; VIEIRA, R.D. Automated system of seedling image analysis (SVIS) and electrical conductivity to assess sun hemp seed vigor. Revista Brasileira de Sementes, v.34, n.1, p.55-60, 2012. http://dx.doi.org/10.1590/ S0101-31222012000100007

SILVA, H.; COSTA, L.; RESENDE, O.; OLIVEIRA, D.; SOARES, R.; VALE, L. Thermodynamic properties of pepper seeds - variety "Cabacinha". Cientifica, v.44, n.1, p.14-22, 2016. http://dx.doi. org/10.15361/1984-5529.2016v44n1p14-22

SPADA, J.C.; NOREÑA, C.P.Z.; MARCZAK, L.D.F.; TESSARO, I.C. Water adsorption isotherms of microcapsules with hydrolyzed pinhão (Araucaria angustifolia seeds) starch as wall material. Journal of Food Engineering, v.114, n.1, p.64-69, 2013. https://doi. org/10.1016/j.jfoodeng.2012.07.019
TANG, Y.; LI, X.; ZHANG, B.; CHEN, P.X.; LIU, R.; TSAO, R. Characterisation of phenolics, betanins and antioxidant activities in seeds of three Chenopodium quinoa Willd. genotypes. Food Chemistry, v.166, p.380-388, 2015. http://doi.org/10.1016/j. foodchem.2014.06.018

XIAO, Q.; TONG, Q. Thermodynamic properties of moisture sorption in pullulan-sodium alginate based edible films. Food Research International, v.54, n.2, p.1605-1612, 2013. https://doi. org/10.1016/j.foodres.2013.09.019 